\title{
Some Things Borrowed, Some Things New: Toward a Multi-Sites of Power Approach to State Theory
}

\author{
Davita Silfen Glasberg and Deric Shannon ${ }^{1}$
}

State theories have consistently focused on the relationship between the state and economic or class actors that reproduces largely capitalist class relations through the state's authority to create policy. There have been highly spirited debates among these class-based models for decades. But there are many state power and policymaking concerns clustering around substantial issues, such as race, gender, and sexuality that significantly affect the organization of society. We suggest borrowing from and building on Jessop's (1990) concepts of state projects, balance of class forces, and selectivity filters to develop a framework that can also account for race, gender, sexuality and their intersections - a multi-sites of power approach to state theory. [Article copies available for a fee from The Transformative Studies Institute. E-mail address: journal@transformativestudies.org Website: http://www.transformativestudies.org (C2015 by The Transformative Studies Institute. All rights reserved.]

KEYWORDS: State Theory, Power, State Projects, Intersectionality, Selectivity Filters.

\footnotetext{
${ }^{1}$ Davita Silfen Glasberg is Associate Dean of Social Sciences in the College of Liberal Arts and Sciences at the University of Connecticut, and a Professor of Sociology, and is the Past President of Sociologists Without Borders. She has taught both undergraduate and graduate courses and authored or coauthored 6 books and dozens of scholarly journal articles on issues of power and oppression, human rights, finance capital and the state, predatory lending, and inequality and diversity. Address correspondence to: Davita Silfen Glasberg; e-mail: davita.glasberg@,uconn.edu.

Deric Shannon is a former line cook, convenience store clerk, and fast food worker, now an Assistant Professor of Sociology at Oxford College of Emory University. He is the editor of The End of the World As We Know It? Crisis, Resistance, and the Age of Austerity and co-author (with Davita Silfen Glasberg) of Political Sociology: Oppression, Resistance, and the State. His current research focuses on global political economy, the sociology of food, and ecology. Address correspondence to: Deric Shannon; e-mail: deric.shannon@emory.edu.
} 